\title{
The Impact of Educational Material Use on Mathematics Achievement: A Meta-Analysis
}

\section{Ümit Kul}

Asst. Prof., Artvin Coruh University, Turkey, umitkul@artvin.edu.tr

\section{Sedef Çelik}

Research Asst., Artvin Coruh University, Turkey, sedefcelik@artvin.edu.tr

Zeki Aksu

Asst. Prof., Artvin Coruh University, Turkey, zekiaksu25@artvin.edu.tr

As a result of rapid development in technology, utilizing materials in education has become important. To date, researchers have often explored the effects of using educational materials in mathematics instruction on academic achievement. The purpose of this study was to combine the empirical evidence regarding the effectiveness of educational materials in mathematics. For this aim, a meta-analysis method was used in the current research. In line with the aim of the research, 54 experimental studies published between years of 2005 and 2016 were included in the meta-analysis and 58 effect sizes were calculated from these studies. The results of the meta-analysis showed that using materials in mathematics has a positive and high influence on achievement. According to analysis of mediator variables that are related to instructional characteristics, significant differences are found in the variables of mathematics topic, type of material, and application time. However, teaching with materials in mathematics did not seem to differ in effectiveness from teaching without materials, in terms of methodological characteristics of the studies.

Keywords: educational materials, meta-analysis, student achievement, teaching mathematics

\section{INTRODUCTION}

Learners construct increasingly complex knowledge through active involvement with educational materials (Dienes, 1973). To achieve this, utilization of different forms of tools and materials becomes necessary in education as well as in other areas. After all, when national curriculums and textbooks are examined, it is observed that there is at least one activity related to each learning objectives, and hence, the appropriate educational materials are suggested for teachers to use in their teaching of mathematics

Citation: Kul, Ü., Çelik, S., \& Aksu, Z. (2018). The Impact of Educational Material Use on Mathematics Achievement: A Meta-Analysis. International Journal of Instruction, 11(4), 303-324. https://doi.org/10.12973/iji.2018.11420a 
in relation to almost every activity (Kablan et al., 2013). Within this context, effective use of instructional materials such as concrete and digital (computer-based application) are regarded as a crucial aspect of the newly developed mathematics curriculum (Demirel \& Altun, 2012; MONE, 2017). Studies on using teaching materials in mathematics revealed various benefits for learners (Bozkurt \& Akalın, 2015; Clements, 1999; Duru \& Korkmaz, 2010; Suh et al., 2005). For instance, using educational materials during teaching and learning processes helps students to develop psychomotor skills especially. Similarly, NCTM published a report in 2000 suggesting that students should be provided with access to educational materials in order to improve their mathematical understanding. A student-centered approach has been adopted and teaching materials have been integrated into learning environments. Within this framework, teachers are requested to efficiently use educational materials in learning environments (Billstein et al., 2009; Gürbüz, 2010). Recently, using educational materials in teaching mathematics has gained importance to concretize concepts and relations. Using materials in teaching is proven to be an effective instructional strategy especially to increase the success of students in mathematics (Sherman \& Bisanz, 2009). In order to learn abstract mathematical concepts, it is necessary to use models (Carbonneau et al., 2013). With the help of educational materials, students develop positive attitudes towards learning and teachers arouse their interest, ensure their active participation and enhance their critical thinking skills (Apperson et al., 2006). Utilizing different kinds of materials helps to cover mathematical concepts from simple to complex and from concrete to abstract especially at primary school level (MONE, 2017). As a result, educational materials become one of the important educational factors that enable students to learn mathematics meaningfully and represent abstract concepts visually. In learning environments where mathematical concepts are represented by different models, students are able to construct mathematical understanding (Moyer, 2001). Students are also able to associate these concepts with their previous knowledge and experience. As students interpret the things they do themselves more easily, it is important for them to construct their own mathematical knowledge. However, a range of practical and pedagogical issues related to utilizing educational materials during teaching make it difficult for teachers to implement them effectively in classrooms (Ünlü, 2017).

\section{The role of using materials in mathematics education}

Swan and Marshall (2010) redefines mathematics materials as "an object that can be handled by an individual in a sensory manner during which conscious and unconscious mathematical thinking will be fostered" (p. 14). Therefore, mathematics manipulatives are materials from our own environment that students can touch and move to learn or formalize mathematical ideas. In this context, materials are found in two groups: the physically represented form of concrete materials, and the computer produced form of digital materials (Burns \& Hamm, 2011; Moyer, 2001). Educational materials are sometimes in digital environments and sometimes they are in the form of physical objects. For education, manipulative materials are used for concretize the abstract concepts to be taught. Tangrams, algebra tiles, isometric paper, colorful beads, game cards, scale, pattern blocks, unifix cubes, and caricatures are examples of physical 
materials that have been used in teaching mathematics for years (NCTM, 2000). Learners worked directly with these materials. Digital manipulations are computer applications and software copies of web-based applications. These computer applications can be accessed online. Once technology is widespread at schools, computer-based electronic materials are easy to access. Digital materials enable teachers to integrate pictorial, verbal, and symbolic representations of mathematics problems more easily. The main difference between physical and digital materials is that you can touch the physical materials (Karakırık \& Aydın, 2016). Teaching with digital material provides more flexibility for manipulation, whereas physical materials enable students to develop their psychomotor learning skills as they address the sense of 'touching' (Olkun, 2003). Materials in a web-based environment provide opportunities for interactivity; learner can rotate, flex and reshape the object easily in virtual environments. In addition, there is a need to use computer applications in teaching of mathematics as an instructional material (Bozkurt \& Akalın, 2010; Burns \& Hamm, 2011). Within this respect, it is important for students to interpret the concepts through real and concrete experiences. In Burns and Hamm's research (2011) few studies were found which support the idea that digital materials should be used more than physical materials. Similarly, according to Reimer and Moyer (2005), the advantage of using digital materials rather than physical material is that technology-based materials are easily accessible and they associate abstract symbols with visual images. Utilizing technology in mathematics has positive effects on the quality of teaching and learning. Integrating instructional activities in appropriate contexts also affects learning positively (Baki \& Çakıroğlu, 2010).

There is a large volume of published studies describing the effect of using digital or physical materials in teaching of mathematics on academic achievement of students. Most of these studies have found that using instructional materials in mathematics lessons has more positive contributions to student learning compared to the lessons where none of the instructional materials are used (Aburime, 2007; Clements, 1999; Gürbüz, 2010; Ojose \& Sexton, 2009; Manches et al., 2010; Olkun, 2003). Thompson (1992) reported that using materials did not have a significant effect on student success. Some researchers also found no effect or negative effects of using materials on student achievement in mathematics (McNeil \& Jarvin, 2007; Moyer-Packenham \& Suh, 2012). There can be several reasons for this inconsistency. For example, factors such as duration of treatment, knowledge of teachers, type of the material, age-level of the students and other characteristics of the learning environment may affect the process. For this reason, there is a need for systematic investigation of available experimental studies about the effects of using educational materials in mathematics lessons on academic achievement of students. In Turkey, there is a considerable amount of studies about the effects of utilizing instructional materials in classroom environment and these instructional materials are also suggested in the revised curriculum. There are several other studies about the effectiveness of instructional materials. This indicates a need to combine all these individual and multiple studies and to systematically analyze them in a single study. This single study will contribute to the literature. For this reason, researchers have often attempted to compare the effectiveness of using educational materials in mathematics education with outcomes of teaching without 
using such materials (Aburime, 2007; Clements, 1999; Gürbüz, 2010; Kablan, 2010; Sowell, 1989; Şengül \& Körükcü, 2012; Yuan et al., 2010).

Despite the fact that a large number of meta-analysis studies have been carried out in other countries, there is a limited study on meta-analyses published about the effects of using materials in mathematics education in Turkey. For example, Kablan et al. (2013) used different material types (power point, animations, cartoons...etc.) and searched for an answer to this question: Does material use in education affect academic the achievement of students? They tried to obtain the answer to this question for 11 different courses. They found that using materials in teaching positively affected academic achievement of students, but student success did not vary by education level, course type and material type. In Demir and Başol's study (2014), the effects of using computerbased materials on student success were investigated and positive effects were found, but their meta-analysis study did not include studies regarding using concrete materials. There is a limited number of empirical evidence on comparisons of digital and physical materials to determine if teachers use digital and physical materials or do not use to teach mathematics. In addition, this study is different from the previous studies, aimed to investigate the effects of all forms of mathematics materials used as a teaching material except textbooks on academic achievements of students in different grade levels. This meta-analysis study included empirical research on using mathematics materials. This paper addresses this gap in literature by examining the relative instructional efficiency of digital and physical materials. In addition, as a result of the research, the extent to which the use of teaching materials in mathematics lessons and the moderator variables affecting the use of materials in mathematics are explained in detail in Turkey, this study will shed light on the work to be done. In this respect, it is important for researchers to investigate who gave the education to students, how long the education was, how it was applied, in which learning areas the materials were used, which type of materials were used because the results found out from this investigation are all important information for the design of learning environments.

\section{The Aim of the Study}

The main aim of this study is to determine the effects of teaching mathematics with educational materials on student achievement as compared to the traditional teaching by analyzing studies published between the years 2005 and 2016. The reason behind is that the mathematics curriculum was revised according to the constructivist approach in 2005 in Turkey. In accordance with this main aim, solutions are sought to the subproblems below: 1) What is the average use of educational materials in mathematics education when compared to traditional teaching? 2) What is the average effect of utilizing educational materials on student achievement in terms of methodological characteristics? 3) What is the average effect of utilizing educational materials on student achievement in terms of instructional characteristics?

\section{METHOD}

In this study, the meta-analysis method was used to make a systematic and integrated review of the published and unpublished studies about the use of educational materials 
in mathematics education. Meta-analysis is a powerful methodological tool that summarizes results of independent and multiple studies to find solutions for the same problem and provides a general result (Glass, 1976; Lipsey \& Wilson, 2001). Therefore, it allows combination and comparison of a lot of statistical data from different studies on a specific topic in order to identify patterns (Scherr, 2004). In order to investigate the effects of instructional materials used in teaching mathematics on academic achievement by using the meta-analysis method, 3 steps were followed for data collection.

\section{Review of literature}

In order to select the studies to be included in the meta-analysis, the literature was reviewed systematically. An attempt was made to access all published and unpublished studies that focus on the effects of instructional materials use in mathematics education on student achievement. In line with the aim of the research, the Google Scholar search engine, ULAKBIM National Combined Catalogue service and academic database of Turkish National Thesis Center of the Council of Higher Education were used in January 2017. Using the 'advanced search' tool of this database, theses written between the years 2005 and 2016 were detected on the basis of title, abstract and keywords. The keywords were as follows; 'mathematics education and material, 'concrete material and achievements' and 'digital material and achievements'. After an extensive literature review, 391 articles, master and doctoral theses were selected. However, 54 studies which fit the purpose of the study were identified.

\section{Criteria for inclusion of the studies}

After an extensive literature review regarding the use of educational materials in mathematics education, the researchers determined criteria for selecting the studies about the effects of teaching mathematics with educational materials on mathematics achievement of students. In accordance with the inclusion criteria, studies related to the use of educational material in mathematics education were collated. However, to calculate the effect size, studies without the necessary statistical data and explanations about moderator variables were not included. This meta-analysis study included empirical research on using digital and physical mathematics materials such as algebra tiles, animation, scales, virtual and concrete geoboard, pattern blocks, model sphere, cartoons, software, pictorial representations, web-sites and virtual objects. Research on using textbooks, worksheets, printed materials etc. was not included in meta-analysis. Published and unpublished studies in the relevant area that abided by the inclusion criteria were chosen. Explanations related to the inclusion criteria determined by the researchers are shown in Table 1.

Table 1

Explanation of criteria for inclusion of the studies

\begin{tabular}{ll}
\hline Criteria for inclusion & Explanation \\
\hline Topic of the Study & To be a study on mathematics education \\
Date of publication & To be published between the years 2005-2016 \\
Sampling & Primary, Middle, High Schools and Universities \\
Design of experimental research & To be in post-test control group design \\
Investigation of student success & Analyzing success of students as a dependent variable
\end{tabular}


Investigation of material usage Analyzing the utilization of instructional materials in mathematics lessons as an independent variable

Having sufficient numerical data Presenting statistical data for both experimental and control groups such as sample size, standard deviation, and arithmetic mean values.

\section{Coding Process}

Coding is putting the studies in an order according to their characteristics (Başol \& Göçmen, 2004). In this research, after the criteria for inclusion of the studies were determined, the studies included in meta-analysis were coded through a coding form prepared by the researchers. The studies that investigated the effect of using materials on students' success in mathematics were coded with the help of this coding form. Of the 391 studies determined in the literature scan, 54 studies abiding by the criteria on the coding form were included in the meta-analysis. These independent studies had 58 effect sizes calculated in this research. In this way, the reason for the effect size being greater than the number of studies is due to 4 studies containing different experimental and control groups. For example, some studies included 2 experimental and 2 control groups. As the sampling groups were different, for these groups the arithmetic mean, standard deviations and sampling size values were different. As a result, effect sizes were calculated for these groups. Thus 58 effect sizes were included in the evaluation and coded on the coding form prepared in Microsoft Excel 2010.

The coding form used in this study is composed of 3 main parts. The first part is "Identification of the studies" which has information about studies such as "number of the study', 'name of the study' and 'author's name'. Second part includes "Data of the study" which has statistical data such as mean values and standard deviations of experimental and control groups and also sample sizes. The third part is "Characteristics of Study Content" which has information about the content of the studies. The characteristics related to the content of the studies are divided into two groups as methodological and instructional. The factors determining methodological and instructional characteristics are explained below.

\section{Methodological Characteristics}

Year of publication: Studies about using mathematics materials in teaching that were published between the years 2005 and 2016 were included in the study. This is because presenting the 10 years from 2005 to 2016 in 2 groups makes the results clearer and more understandable.

Type of the study: This meta-analysis study included all studies both published and unpublished appropriate to the aim of the research. Consequently, types of the study is a mediator variables that was coded as a 'master thesis, 'doctoral thesis', or 'articles'.

Study Design: Studies that were carried out to determine the effects of teaching mathematics with materials on achievement of students were gathered together in this research. Experimental studies can be classified differently between themselves (Fraenkel et al. 2012; McMillan and Schumacher 2006). Therefore, experimental designs of the studies were coded as 'true experimental' or 'quasi-experimental'. Thus, the desire was to protect the originality of the data in the study. 
Sample Group: The sample groups were coded as 'primary school, 'middle school, 'high school' and 'university'. In Turkey the age interval for primary school is 6-9 years, the age interval for middle school students is 10-13 years and the age interval for high school students is $14-17$ years.

Measurement Tool: Outcome measures were classified as being researcher developed or standardized assessments instruments found in the literature. Reliability and validity processes were carried out for both types of instruments and also because researchers were aided by the questions from other studies' instruments found in the national thesis center while developing their own measurement tools.

Table 2 below illustrates the methodological characteristics of 54 studies included in meta-analysis with their frequency and percentage values.

Table 2

The frequency and percentage values of methodological characteristics

\begin{tabular}{|c|c|c|c|c|c|}
\hline Characteristics & 1 & 2 & 3 & 4 & To \\
\hline Publication year of research & $2005-2010$ & 2011-2016 & & & \\
\hline $\mathrm{n}$ & 30 & 24 & & & 54 \\
\hline$\%$ & 55.55 & 44.45 & & & 100 \\
\hline Type of research & Master thesis & Doctoral thesis & Article & & \\
\hline $\mathrm{N}$ & 37 & 5 & 12 & & 54 \\
\hline$\%$ & 68.53 & 9.25 & 22.22 & & 100 \\
\hline Research Design & True Experimental & Quasi-experimental & & & \\
\hline $\mathrm{N}$ & 32 & 22 & & & 54 \\
\hline$\%$ & 59.25 & 40.75 & & & 100 \\
\hline Sample & Primary School & Middle School & High School & University & \\
\hline $\mathrm{N}$ & 5 & 33 & 12 & 4 & 54 \\
\hline$\%$ & 9.25 & 61.13 & 22.22 & 7.40 & 100 \\
\hline Measurement Tool & Researcher developed & Ready instrument & & & \\
\hline $\mathrm{N}$ & 47 & 7 & & & 54 \\
\hline$\%$ & 87.03 & 12.97 & & & 100 \\
\hline
\end{tabular}

As can be seen from Table 2 above, the studies included in the meta-analysis were classified depending on year of the study, study type, research method used in the study, sampling type used in the study and whether the achievement test was developed within the study.

\section{Instructional Characteristics}

Mathematics Topics: Mathematics topics taught to students for the implementation of the studies were coded as 'Numbers and Algebra', 'Geometry and Measurement' or 'Data'. In Turkey the learning areas for the elementary school mathematics program were determined as numbers and processes, algebra, geometry, measurements and data; different to this program in $8^{\text {th }}$ class of middle school probability is added (MONE, 2017). The learning areas in the high school mathematics program are numbers and algebra, geometry and measurement and data. These three topics were determined as mathematics topics to be taught because they are three basic topics in the high school mathematics curriculum (MONE, 2010). Though these learning areas are not used in higher education, one or more than one of the topics determined in this study were classified in the mixed category. 
Type of Materials: In this context, mathematics materials are found in two groups: the physically represented form of concrete materials, and the computer produced form of digital materials (Burns \& Hamm, 2011; Demirel \& Altun, 2012; Moyer, 2001). Educational materials are sometimes in digital environments and sometimes they are in the form of physical objects. For this reason, material types used in teaching mathematics were coded as 'physical', 'digital' and 'both physical and digital'. Tangrams, algebra tiles and caricatures are examples of physical materials that have been used in teaching mathematics for years (NCTM, 2000). Digital manipulations are computer produced materials and software copies of web-based applications. Once technology is widespread at schools, computer-based electronic materials are easy to access. The main difference between physical and digital material is that you can touch the physical materials.

Implementer: People who use the material in mathematics lessons were coded in 3 different categories as 'teacher', 'researcher' and 'both teachers and researchers'.

Method of using Materials: The ways of using mathematics materials were coded in 4 different categories as 'individual', 'small group', 'full participation' and mixed'. Application Time: The duration of material usage was coded in 5 categories as 5-10 hours, 11-15 hours, 16-20 hours, 21-30 hours and more than 30 hours. Instructional characteristics of 54 studies are presented in Table 3

Table 3

The frequency and percentage values of instructional characteristics

\begin{tabular}{|c|c|c|c|c|c|c|}
\hline Characteristics & 1 & 2 & 3 & 4 & 5 & To \\
\hline Mathematical Topics & Numbers \& Algebra & Geometry \& Measurement & Data & Mixed & & \\
\hline $\mathrm{n}$ & 24 & 24 & 1 & 5 & & 54 \\
\hline$\%$ & 44.44 & 44.44 & 1.85 & 9.27 & & 100 \\
\hline Material Type & Physical & Digital & Both & & & \\
\hline $\mathrm{n}$ & 24 & 29 & 1 & & & 54 \\
\hline$\%$ & 44.44 & 53.71 & 1.85 & & & 100 \\
\hline Implementer & Researcher & Teacher & $\begin{array}{l}\text { Teacher as a } \\
\text { Res. }\end{array}$ & & & \\
\hline $\mathrm{n}$ & 29 & 17 & 8 & & & 54 \\
\hline$\%$ & 53.71 & 31.48 & 14.81 & & & 100 \\
\hline $\begin{array}{l}\text { Method } \\
\mathrm{n} \\
\%\end{array}$ & $\begin{array}{l}\text { Individual } \\
6 \\
11.12\end{array}$ & $\begin{array}{l}\text { Small group } \\
28 \\
51.85\end{array}$ & $\begin{array}{l}\text { Full parti. } \\
12 \\
22.22\end{array}$ & $\begin{array}{l}\text { Mixed } \\
8 \\
14.81\end{array}$ & & $\begin{array}{l}54 \\
100\end{array}$ \\
\hline Application Time & $5-10$ & $11-15$ & $16-20$ & $20-30$ & $\begin{array}{l}\text { Over } \\
30\end{array}$ & \\
\hline$n$ & 14 & 27 & 7 & 3 & 3 & 54 \\
\hline$\%$ & 25.94 & 50 & 12.96 & 5.55 & 5.55 & 100 \\
\hline
\end{tabular}

\section{Data Analysis}

Statistical data from studies included in the meta-analysis about the use of learning materials were analysed after coding on the coding form. The treatment effect metaanalysis methods were used for data analysis. In this way the basic aim of treatment efficacy is shown with the formula $\mathrm{d}=(\mathrm{Xe}-\mathrm{Xc}) / \mathrm{SD}$ for experimental studies with the differences between the means of the control and experimental groups calculated 
(Hunter and Schmidt 1990). The values related to the 58 effect sizes in this metaanalysis study were written on the coding form prepared with Microsoft Excel 2010. The numerical values obtained in the study were transformed into a standardized effect size to ensure equivalent measurements related to the standard deviations of each study (Hartzler 2000). Moreover, the type of the meta-analysis used determines the effect size (Kock 2009). A standardized effect size which is represented with 'd' or ' $g$ ' is used in the treatment effect (Şahin, 2005). In the present study, in order to calculate the effect size standardized mean difference "Cohen's $d$ " was used. Therefore, this measure of effect size is frequently elucidated in studies examining the effect of a manipulated independent variable (e.g., materials vs. control) on a continuous dependent variable (e.g., achievement). When study statistics were not directly stated, Cohen's d values were computed with reported descriptive statistics or observed $\mathrm{F}$ or $\mathrm{t}$ statistics (Rosenthal 1984). In addition, the results were interpreted according to the effect size classification of Cohen (1998). In this meta-analysis study, each meta-analyzed study's effect size values and combined effect size were calculated and calculations on moderator variables and on publication bias were completed with the assistance of Comprehensive Meta-Analysis (CMA) Software v2.0.

\section{Analysis of Moderator Variables}

The variables that might moderate the effects of teaching mathematics with materials were determined. For the investigation of methodological and instructional moderator variables that were determined, statistical analyses were carried out with $\mathrm{Qb}(\mathrm{Q}-$ between) values. In other words, $\mathrm{Qb}$ value was used in order to determine the significant differences between the moderator variables.

\section{Publication Bias}

Publication bias is a widespread problem that should definitely be investigated in metaanalyses. As each method has strengths and weaknesses, different statistical methods should be used to detect publication bias and to identify to what extent that bias affects results (Üstün \& Eryılmaz 2014). For this reason, more than one method was used to test for publication bias in this meta-analysis study. The funnel plot, Duval and Tweedie's trim and fill test and Rosenthal's fail safe $\mathrm{N}$ value were used to test publication bias. The funnel plot provides the effect estimations obtained from single research as a measure of the size or sensitivity of the study (Sterne et al. 2011). Duval and Tweedie's trim and fill test reveals possible missing studies in meta-analysis and was used to test this effect for the studies in this meta-analysis (Duval \& Tweedie, 2000). Finally, Rosenthal's fail safe N value was obtained to determine how many studies are required to negate the studies included in the meta-analysis (Borenstei et al., 2009). As this meta-analysis included theses and articles, the difference between effect sizes of published and unpublished studies was examined. In this way, the publication bias was tested using several different methods. Firstly, the funnel plot method was used to detect publication biases. Figure 1 below illustrates the Funnel Plot for the studies included in the meta-analysis. 


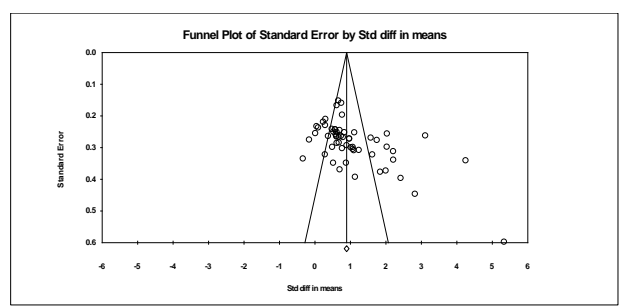

Figure 1

Funnel plot of effect size related to publication bias

As shown in Figure 1, no publication bias is seen in the meta-analysis. When the funnel plot has an asymmetric distribution and severe skewness, it means that publication bias exists. Publication bias is clearly present especially when the skewness increases on a line that shows average effect sizes of studies at the bottom of the funnel plot (Çoğaltay et al., 2014). As such there is no extremely asymmetric distribution observed on Figure 1. As a result, it can be said that there is no publication bias for the studies included in the research. Although publication bias was not observed in this meta-analysis according to the Funnel Plot method, several other methods for detecting publication bias were also used. One of these methods is 'Duval \&Tweedie's Trim and Fill' Test. Table 4 shows the results of 'Duval \& Tweedie's Trim and Fill' test.

Table 4

Results of 'Duval\& Tweedie's Trim and Fill' test

\begin{tabular}{llllll}
\hline & $\begin{array}{l}\text { Excluding } \\
\text { Study }\end{array}$ & Point Estimate & \multicolumn{2}{l}{ 95\% Confidence Interval (CI) } & Q \\
\cline { 4 - 5 } & & & Lower bound & Upper bound & \\
\hline Observed Values & & 1.047 & 0.844 & 1.249 & 48.132 \\
$\begin{array}{l}\text { Adjustment } \\
\text { Values }\end{array}$ & 0 & 1.047 & 0.844 & 1.249 & 484.132 \\
\hline
\end{tabular}

As can be seen from the table above, there is no significant difference between observed values and the values that are adjusted to eliminate the influence of publication bias. As a result there should be no missing data on the right and left sides of the central line and the studies to the right and left of this line should display a symmetric distribution. In addition to this test, In addition to this test, the Rosenthal' fail safe-N test was also implemented to investigate the publication bias of the studies included in the metaanalysis. Table 5 shows the results of the Rosenthal' fail safe-N test.

Table 5

Classic fail-safe name

\begin{tabular}{ll}
\hline Resistance of the Meta-Analysis versus Publication Bias & \\
\hline z-value & 27.220 \\
p-value & 0.000 \\
Alpha-value & 0.050 \\
Alpha-value for z value & 1.959 \\
$\mathrm{~N}$ & 58 \\
$\mathrm{p}>$ the number of missing studies for the alpha result & 1130.00 \\
\hline
\end{tabular}

Examining the number of Rosenthal' Fail Safe-N as shown in Table 5, 1130 studies are needed to nullify the results of the meta-analysis. Additionally, the results of these 1130 studies should be in contrast with the results of this meta-analysis. Finally, another 
analysis is included to test publication bias. The difference between the effect sizes of both published and unpublished studies should be examined.

Table 6

Difference of effect sizes according to publication status (Publication Bias Analysis)

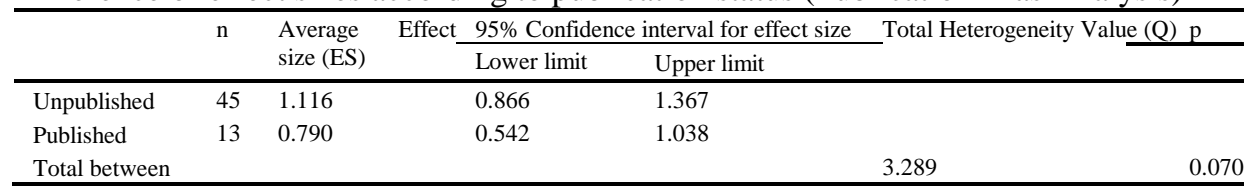

As seen in Table 6, there is no publication bias of published and unpublished studies observed. Considering the results of all these publication bias tests, it can be said that no publication bias exists in the meta-analysis results.

\section{FINDINGS}

This research was carried out to investigate the effects of using materials in teaching mathematics on the academic achievement of students. Fifty-eight effect sizes from 54 studies were used in total and 3859 students participated in these studies. Of the students, 1923 were in control groups with 1936 of the students in study groups. Analyzing the homogeneity and heterogeneity statistics, it can be seen that the $\mathrm{Q}$ value is significant $[Q=484.132, p<0.05]$. This reveals that there is a high heterogeneity in the study (Cooper et al. 2009). Considering these results, the decision was made to use a random model in the study. Table 7 below provides average effect sizes of the studies included in the meta-analysis and their confidence intervals according to the randomeffect model.

Table 7

Results related to random- effect model

\begin{tabular}{|c|c|c|c|c|c|c|c|c|}
\hline \multirow[t]{2}{*}{ Model Type } & \multirow[t]{2}{*}{$\mathrm{n}$} & \multirow[t]{2}{*}{$\mathrm{Z}$} & \multirow[t]{2}{*}{ SE } & \multirow{2}{*}{$\begin{array}{l}\text { Total } \\
\text { Heterogeneity } \\
\text { Value (Q) }\end{array}$} & \multirow{2}{*}{$\begin{array}{l}\text { Average } \\
\text { Effect size } \\
(\mathrm{ES})\end{array}$} & \multicolumn{2}{|c|}{$\begin{array}{l}95 \% \text { Confidence interval for } \\
\text { effect size }\end{array}$} & \\
\hline & & & & & & Lower bound & Upper bound & \\
\hline Random-Effect Model & 58 & 10.134 & 0.103 & 48.132 & 1.047 & 0.845 & 1.250 & 0.00 \\
\hline
\end{tabular}

The result of meta-analysis according to random-effect model shows that the average effect size is $1.047(\mathrm{p}<0.05)$. This value presents the effect of using materials in mathematics lessons on the academic achievement of students and it is a positive and high effect according to Cohen (1998).

\section{Effect Sizes related to Moderator Variables}

In this study instructional and methodological moderator variables were investigated to determine the effects of using materials on academic achievement. Moderator variables related to methodology are study type, study design, sample group that the study was conducted on and measurement tools for assessing academic achievement. On the other hand, instructional moderator variables are the variables that are related to material usage in classroom environment. Mathematics topics to be taught with the materials, type of the material used, people who applied the material, the method of using material and duration of material usage are the variables related to instruction. Results regarding the analysis of methodological variables are set out in Table 8. 
Table 8

Results regarding the analysis of methodological moderator variable

\begin{tabular}{|c|c|c|c|c|c|c|c|}
\hline \multirow[t]{2}{*}{ Moderator } & \multirow[t]{2}{*}{$\mathrm{k}$} & \multirow[t]{2}{*}{$\mathrm{d}$} & \multirow[t]{2}{*}{ SE } & \multicolumn{2}{|c|}{$95 \%$ Confidence Interval $(\mathrm{CI})$} & \multirow[t]{2}{*}{$\mathrm{Qb}$} & \multirow[t]{2}{*}{$\mathrm{p}$} \\
\hline & & & & Lower limit & Upper lim. & & \\
\hline Study type & & & & & & 3.569 & 0.168 \\
\hline Master Thesis & 39 & 1.106 & 0.143 & 0.825 & 1.370 & & \\
\hline Doctoral Thesis & 6 & 1.192 & 0.271 & 0.660 & 1.723 & & \\
\hline Article & 13 & 0.790 & 0.127 & 0.542 & 1.038 & & \\
\hline Design & & & & & & 2.638 & 0.104 \\
\hline Experimental & 35 & 0.896 & 0.097 & 0.705 & 1.087 & & \\
\hline Quasi-experimental & 23 & 1.281 & 0.216 & 0.857 & 1.705 & & \\
\hline Sample Group & & & & & & 1.317 & 0.725 \\
\hline Primary School & 6 & 0.783 & 0.284 & 0.225 & 1.340 & & \\
\hline Middle School & 34 & 1.027 & 0.128 & 0.775 & 1.278 & & \\
\hline High School & 12 & 1.193 & 0.226 & 0.751 & 1.635 & & \\
\hline University & 6 & 1.123 & 0.466 & 0.209 & 2.037 & & \\
\hline Measurement tool & & & & & & 1.381 & 0.240 \\
\hline Developed by researchers & 50 & 1.092 & 0.114 & 0.869 & 1.315 & & \\
\hline Ready instrument used before & 8 & 0.777 & 0.243 & 0.300 & 1.253 & & \\
\hline
\end{tabular}

It can be seen from the data in Table 8 that study type is not a significant moderator variable for academic achievement [ $Q b=3,569, p>0.05]$. In other words, the form of the study, i.e., a master, doctoral thesis or article, does not change its average size effect on academic performance. Similarly, study design is not a significant moderator variable $[Q b=2.638, p>0.05]$. So, the design of the study as true experimental or quasiexperimental does not change its average size effect on academic performance. Moreover, sample size does not have a moderator role in academic achievement of the students $[Q b=1.317 p>0.05]$. In other words, whether the study was conducted in primary, middle, high school or university does not vary the value of average effect size. Another variable analyzed for its moderating effect was measurement tool and it was found that this variable is not a significant moderator for achievement $[Q b=1.381, p>$ 0.05]. So, using a measurement tool developed by the researcher or using an instrument used before in other studies in the literature to assess academic achievement does not change the value of average effect size. Results related to instructional moderators for the effect of teaching mathematics with materials on academic achievement of students are shown in Table 9.

Table 9

Results regarding the analysis of instructional moderator variables

\begin{tabular}{|c|c|c|c|c|c|c|c|}
\hline \multirow[t]{2}{*}{ Moderator } & \multirow[t]{2}{*}{$\mathrm{K}$} & \multirow[t]{2}{*}{$\mathrm{d}$} & \multirow[t]{2}{*}{ SE } & \multicolumn{2}{|c|}{$95 \%$ Confidence Interval $(\mathrm{CI})$} & \multirow[t]{2}{*}{$\mathrm{Qb}$} & \multirow[t]{2}{*}{$\mathrm{p}$} \\
\hline & & & & Lower 1. & Upper 1. & & \\
\hline Mathematical topic & & & & & & 17.498 & 0.001 \\
\hline Numbers and Algebra & 26 & 0.967 & 0.126 & 0.721 & 1.214 & & \\
\hline $\begin{array}{l}\text { Geometry and } \\
\text { Measurement }\end{array}$ & 25 & 1.258 & 0.187 & 0.892 & 1.624 & & \\
\hline $\begin{array}{l}\text { Data, counting and } \\
\text { probability }\end{array}$ & 1 & -0.325 & 0.336 & -0.984 & 0.333 & & \\
\hline Mixed & 6 & 0.769 & 0.257 & 0.265 & 1.273 & & \\
\hline Type of Materials & & & & & & 12.224 & 0.002 \\
\hline Physical & 24 & 0.943 & 0.138 & 0.673 & 1.213 & & \\
\hline Digital & 33 & 1.076 & 0.149 & 0.785 & 1.368 & & \\
\hline
\end{tabular}




\begin{tabular}{|c|c|c|c|c|c|c|c|}
\hline Both & 1 & 2.222 & 0.340 & 1.556 & 2.889 & & \\
\hline Implementer & & & & & & 4.671 & 0.097 \\
\hline Researcher & 32 & 1.206 & 0.154 & 0.904 & 1.508 & & \\
\hline Teacher & 18 & 0.974 & 0.177 & 0.686 & 1.262 & & \\
\hline $\begin{array}{l}\text { Researcher as a } \\
\text { Teacher }\end{array}$ & 8 & 0.579 & 0.249 & 0.090 & 1.067 & & \\
\hline Method & & & & & & 5.166 & 0.160 \\
\hline Individual & 6 & 1.083 & 0.265 & 0.564 & 1.602 & & \\
\hline Small group & 31 & 1.090 & 0.131 & 0.834 & 1.346 & & \\
\hline Full participation & 12 & 0.708 & 0.137 & 0.440 & 0.975 & & \\
\hline Mixed & 9 & 1.325 & 0.469 & 0.405 & 2.244 & & \\
\hline Application Time & & & & & & 19.404 & 0.001 \\
\hline 5-10 hours & 15 & 1.043 & 0.192 & 0.666 & 1.420 & & \\
\hline 11-15 hours & 28 & 0.913 & 0.115 & 0.687 & 1.138 & & \\
\hline $16-20$ hours & 9 & 1.782 & 0.425 & 0.949 & 2.615 & & \\
\hline 21-30 hours & 3 & 0.304 & 0.147 & 0.016 & 0.591 & & \\
\hline $\begin{array}{l}\text { More than } \\
30 \text { hours }\end{array}$ & 3 & 0.724 & 0.174 & 0.382 & 1.066 & & \\
\hline
\end{tabular}

Note. $p<0.05$, d=Effect Size; SE= Standard Error; $Q b: Q$ value between groups

As shown in table above, 'mathematical topics' is a significant moderator variable for academic achievement $[Q b=17.498, p<0.05]$. In other words, the topics 'numbers and algebra', 'geometry and measurement', 'data', 'counting' or a mixture of all these topics significantly affect the average size effect on academic achievement. In the studies where geometry and measurement are taught during the experiment, the effect sizes are high and significant $[\mathrm{k}=25, \mathrm{~d}=1.25895 \% \mathrm{CI}(0.892 ; 1.624), p<0.05]$. Similarly, type of the materials used in mathematics lessons has a significant moderator effect $[Q b=$ $12.224, p<0.05]$. So, teaching mathematics either with physical or digital or both types of materials changes the size of the effect on academic achievement. In studies where both physical and digital materials are used for teaching, effect sizes are high and significant $[\mathrm{k}=1, \mathrm{~d}=2.222,95 \%$ CI $(1.556,2.889), p<0.05]$. However, when the moderator role is investigated, the other variable of person applying the material in mathematic lessons does not appear to have a moderating role [ $Q b=4.671, p>0.05]$. In other words, whether the person using the material was the researcher, teacher or both together did not change the mean effect size on academic achievement. Moreover, it was determined that the method of using the material does not have a significant moderator effect $[Q b=5.166, p>0.05]$. This means that whether the material is applied to individual students, students in small groups or to all students in the classroom that is to say with full participation does not change the average effect size value. The last variable investigated for its moderating effect is the duration of material application. According to the results, duration of material application is a significant moderator variable $[Q b=19.404, p<0.05]$. The effect of teaching mathematics with materials on achievement in mathematics changes according to application time. Using the material for 5-10 hours or 11-15 hours or 16-20 hours, 21-30 hours or for more than 30 hours all have moderating role for academic achievement of students. In studies where the materials are applied for 15-20 hours, effect sizes are high and significant $[k=9, d=$ $1.782,95 \%$ CI $(0.949,2.615), p<0.05]$. 


\section{DISCUSSION}

The aim of this meta-analytic review is to explore the effect of teaching mathematics with instructional materials as compared to traditional teaching approaches. In line with the aim of the research, 54 studies were included in the meta-analysis and 58 effect sizes were calculated from these researches. 58 effects sizes of 54 individual studies were included in analysis. The effect size value, that is to say, the effect of using materials in mathematics lessons on academic achievement was found as a positive and high according to Cohen (1998). The aim of this meta-analytic review is to explore the effect of teaching mathematics with instructional materials compared to traditional teaching approaches. In line with the aim of the research, 54 studies were included in the metaanalysis and 58 effect sizes were calculated from these researches. Fifty-eight effects sizes from 54 individual studies were included in the analysis. The effect size value, that is to say the effect of using materials in mathematics lessons on academic achievement, was found to be positive and high according to Cohen (1998). Similarly a meta-analysis study researching the effect of the use of material on academic achievement in geography lessons found a positive and large effect size (Sezer \& İner, 2017). Additionally, a study researching the effect of material use in the classroom on academic achievement in all lessons calculated a positive and large level of effect size (Kablan et al., 2013). In this study of the effect of the use of material on academic achievement in mathematics lessons, the effect size was calculated as positive and large, according to Cohen (1998). In other words, the academic achievement of students who use material in mathematics lessons is higher compared to situations without material use. The results of the research are consistent with the results of the studies by Olkun (2003), Clements, (1999) Suydam and Higgins (1977) on the effect of educational materials use on academic achievement in mathematics lessons. When meta-analysis studies on the use of material on academic achievement, especially in mathematics education, are investigated, similar to this research, the use of material was identified to be effective on academic achievement. For instance, in 1989 Sowell conducted a meta-analysis of 60 studies that compared the learning environment in which materials were used with learning environments in which no material was used. As a result of his meta-analysis, Sowell (1989) showed that students who learnt in the environments where educational materials were applied were more successful than other students who learnt in environments with no instructional materials. Moreover, a meta-analysis on the use of materials in mathematics education found an effect of physical material on academic achievement (Carbonneau et al. 2013). Additionally, an effect was found of another material type, digital material, on academic achievement in mathematics education (Moyer-Packenham \& Westenskow, 2013). All in all, the present study demonstrates that the computed effect size related to the effect of using educational materials in mathematics education on academic achievement of students is high. When all these results are taken into consideration, it is confirmed that using educational materials in mathematics lessons has positive effects on student learning compared to classrooms in which no materials are used (Aburime, 2007; Clements, 1999; Gürbüz, 2010; Ojose \& Sexton, 2009; Manches et al., 2010; Olkun, 2003). 
Another finding of the current meta-analysis is that moderator variables related to methodological characteristics have no significant moderating effect. Study type, that is to say the design of the study as true experimental or quasi-experimental, does not change its average size effect on academic achievement. This outcome is contrary to that of Carbonneau et al. (2013) who found a significant difference between the study designs. The results of their study showed that effect sizes of quasi-experimental studies were higher than the effect sizes of experimental studies. This contrast can be explained because the mathematical learning-teaching processes, which are designed as an experimental and semi-experimental studies which are different from each other. The present meta-analysis shows that different grade levels of students do not change the size of the effect on academic achievement. This result is similar to the results of the study by Kablan et al. (2013). Their study demonstrates that effect sizes do not vary by the grade levels. Another methodological variable investigated for its moderating role in present study is 'measurement tool'. According to the results, this variable is not a significant moderator. So, for the aim of assessing academic achievement, using a measurement tool prepared by the researcher of that study or an instrument developed in other studies does not change the size of the effect on academic achievement. The last finding of the current study is that the variables related to instructional characteristics have significant moderating effect on academic achievement of students. These variables, related to instruction, are mathematical topics, type of materials, and application time. Significant differences were found between these variables. Effect sizes of the mathematical topic 'geometry and measurement' $(\mathrm{d}=1.313)$ are higher than the effect sizes of other mathematical topics. Similarly, Carbonneau et al. (2013) also found that effect sizes of mathematical topics varied, but the effect size of the topic 'fractions' was found to be higher than the effect sizes of other mathematics topics. According to the results of studies carried out in Turkey, we infer that using materials for teaching geometry has more positive effects on academic achievement of students compared to other mathematics topics.

Another instructional variable 'material type', in other words using a physical or a digital material or using both, influences the average size effect on academic achievement. In studies that use both physical and digital materials, effect sizes are significant and high. However, this finding is contrary to a previous meta-analysis conducted by Kablan et al. (2013) about using materials in different courses. They found no significant differences among effect sizes of variables regarding different material types. These different study results related to material type may help us understand that using different material types in mathematics education is quite important for the academic achievement of students. In true experimental and quasi-experimental studies, researchers or teachers may implement the tests or materials to the experimental or control group and topics may be taught by different teachers. All these issues can affect academic achievement of students. Moreover, the level of classroom management skills of the researchers and whether they have enough experience for classroom management or not may affect the results. On the other hand, when only the researcher manages the implementation process, teaching and learning activities are carried out as they should be (Ural \& Bümen, 2016). In this current study, 'implementer' was analyzed as a 
moderator variable and it was found that the effect size on academic achievement did not change when the educational material was used by the researcher or the teacher or by both. In his study, Sowell (1989) found that using materials for a long time had positive effects on student success. However, in the present study using materials in mathematics lessons for 16-20 hours had higher effect size compared to other durations of material use.

\section{CONCLUSION}

From past to present, the effects of teaching mathematics with materials on student achievement were analyzed and different results were found. The results of the present meta-analysis show that using instructional materials have high effects on mathematics achievement according to a random effect model. Moreover, the effect size does not change according to methodological characteristics but it varies mostly due to the instructional characteristics. Physical and digital materials are found to be more effective in mathematics achievement compared to other types of materials. As a result, instructional characteristics should be taken into consideration while designing learning environments. According to the results of meta-analysis conducted for this research, using materials has strong effects on mathematics achievement. Meta-analysis studies give general results about studies that are combined together but they do not explain the reason for the issues focused on in these studies (Çelik, 2013). However, the limitations of the study and recommendations for further research are provided. The first limitation of the present study is that the studies included in the meta-analysis are experimental studies. So, limitations arising from the nature of experimental research should be taken into consideration when results are analyzed and interpreted. For example, the study group can be exposed to a more positive effect called the Hawthorne Effect compared to the control group (Adair et al., 1989). Moreover, this meta-analysis investigates the effect of using materials in mathematics courses only on academic achievement, but further research can be carried out to investigate the relationship between using materials and several other dependent variables (for example; attitude, interest, anxiety...etc.). Another limitation of this research is that it includes only national studies. Studies that are carried out in Turkey are analyzed because it may provide relevant information for researchers, policy makers, and teachers to comprehend the results of the findings and offer suggestions for the mathematics education policy in Turkey. Researchers will be able to better direct their own work with knowledge of the variables that affect the use of materials in mathematics. Thus, in using mathematics lesson teaching material, it is thought that they will be aware of the variables that researchers should consider. For example, in this study, the use of material was found to affect mathematical success in favor of digital material use. However, factors that influence the use of material in mathematics may be different in countries that have achieved success in overcoming mathematics in international exams such as TIMMS and PISA. For this reason, a national assessment can be made in these countries, where the effect of material use on mathematics lessons on academic achievement differs in terms of different moderator variables. Similarly, a larger meta-analysis that includes different international studies carried out in other countries can be conducted to compare 
the effect of using materials in mathematics courses on the academic achievement of students.

\section{REFERENCES}

Note: References marked with an asteriks indicate studies included in the meta-analysis

Aburime, F. E. (2007). How manipulatives affect the mathematics achievement of students in Nigerian schools. Educational Research Quarterly, 31(1), 3-16.

*Akbay, M. (2015). Effect of designing in digital game environment with a constructionist approach, on geometry achievement, self-efficacy and spatial ability of high school students (Unpublished master thesis). Atatürk University, Erzurum, Turkey.

*Akçayır, M. (2011). The effect of using manipulatives in mathematics lesson upon students' motivation, academic success and attitudes (Unpublished master thesis). Gazi University, Turkey.

*Akkaya, R. (2006). The effectiveness of activity based approach in overcoming misconception in the field of learning algebra appeared among the sixth year students (Unpublished master thesis). Abant İzzet Baysal University, Bolu, Turkey.

Apperson, J. M., Laws, E. L., \& Scepansky, J. A. (2006). The impact of presentation graphics on students' experience in the classroom. Computers and Education, 47(1), 116-126.

*Arıc1, S. (2012). The effect of origami-based instruction on spatial visualization, geometry achievement and geometric reasoning of tenth-grade students (Unpublished master thesis). Bogazici University, Istanbul, Turkey.

Baki, A. (2002). Öğrenen ve ögrretenler için bilgisayar destekli matematik [Computer-supported mathematics education for teachers and learners]. İstanbul, Turkey. BİTAV-Ceren Publishing.

*Baki, A., \& Özpınar, İ. (2007). The effects of logo-assisted geometry teaching material on students' academic achievement and students' views on implementation. Cukurova University Journal of Educational Faculty, 34(3), 153-163

Baki, A., \& Çakıroğlu, Ü. (2010). Learning objects in high school mathematics classrooms: Implementation and Evaluation. Computers and Education, 55(4), 1459-1469.

Başol-Göçmen, G. (2004). A general revision of meta-analysis. Sakarya University Journal of Education Faculty, 7, 186-192.

*Bilen, Ö. (2016). Investigation of the Cognitive and Affective Effects of E-Worksheets on Secondary School Students (Unpublished doctoral thesis). Atatürk University, Erzurum, Turkey.

Billstein, R., Libeskind, S., \& Lott, J. W. (2009). A problem solving approach to mathematics: For elementary school teachers. Boston, MA: Addison Wesley.

Borenstein, M., Hedges, L. V., Higgins, J. P. T., \& Rothstein, H. R. (2009). Introduction to MetaAnalysis. West Sussex: John Wiley \& Sons Ltd.

Bozkurt, A., \& Akalın, S. (2010). The importance of material development and use in mathematics education and the role of the teacher. Dumlupinar University Journal of Faculty of Education 27, 47-56.

Burns, B.A., \& Hamm, E. H (2011). A comparison of concrete and virtual manipulative use in third and fourth grade mathematics. School Science and Mathematics, 111(6), 256-261.

Carbonneau, K. J., Marley, S. C., \& Selig, J. P. (2013). A meta-analysis of the efficacy of teaching mathematics with concrete manipulatives. Journal of Educational Psychology, 105(2), 380-400. DOI: $10.1037 / \mathrm{a} 0031084$. 
Clements, D. H. (1999). Concrete manipulatives, concrete ideas. Contemporary Issues in Early Childhood, 1(1), 45-60.

Cohen, J. (1988). Statistical power analysis for the behavioral sciences. Lawrence Erlbaum Associates: London.

Cooper, H. M., Hedges, L. V., Valentine, J., \& Hedges, L. V. (Ed.) (2009). The Handbook of Research Synthesis and meta-analysis. New York: The Russell Sage Foundation.

Çoğaltay, N., Karadağ, E., \& Öztekin, Ö. (2014). The effect of school principals' transformational leadership behaviors on teachers' organizational commitment: a meta-analysis study. Educational Administration: Theory and Practice, 20(4), 483-500. doi: 10.14527/kuey.2014.019

Demir, S., \& Başol, G. (2014). Effectiveness of computer-assisted mathematics education (CAME) over academic achievement: A meta-analysis study. Educational Sciences: Theory \& Practice, 14 (5). pp. 2026-2035.

Demirel, Ö., \& Altun, E. (2012). Öğretim teknolojileri ve materyal tasarımı [educational technology and Material design]. Ankara: Pegem Akademi Yayıncılık.

*Dereli, M. (2007). The effects of teaching the integers subject by cartoon to the students' mathematical success (Unpublished master thesis). Marmara University, Istanbul, Turkey.

Dienes, Z. P. (1973). Mathematics through the senses, games, dance, and art. Windsor, UK: The National Foundation for Educational Research Publishing Company Ltd.

*Dinçer, K.S. (2015). Using concept maps in mathematics: the effects on students' mathematical power (Unpublished master thesis) Yıldız Technical University, Istanbul, Turkey.

Duval, S., \& Tweedie, R. (2000). Trim and fill: A simple funnel-plot-based method of testing and adjusting for publication bias in meta-analysis. Biometrics, 56(2), 455-463.

*Egelioğlu, C. H. (2008). Computer based education has an influence on success and epistemological belief in teaching of sub-learning zones of transformation geometry and areas of quadrangle zones (Unpublished master thesis). Marmara University, Istanbul, Turkey.

*Emlek, B. (2007). Computer aided teaching trigonometry using dynamic modelling (Unpublished master thesis). Selcuk University, Konya, Turkey.

*Enki, K. (2014). Effects of using manipulatives on seventh grade students' achievement in transformation geometry and orthogonal views of geometric figures (Unpublished master thesis). Middle East technical university, Ankara, Turkey.

*Erşen, N.A. (2014). The effect of mathematics teaching supported with material on 6th student success, attitude, concern and permanency of learning (Unpublished master thesis). Firat University, Elazı̆g, Turkey.

*Gelibolu, F.M. (2008). Evaluation of application of computer based materials developed in realistic mathematics approach in 9th grade mathematics lessons. Unpublished master thesis, Ege University, İzmir, Turkey.

*Genç, G., \& Öksüz, C. (2016). Teaching 5th grades polygon and quadrilateral subjects through dynamic mathematic software. Kastamonu Education Journal, 24(3), 1551-1566.

Glass, G. (1976). Primary, secondary and meta-analysis of research. Retrieved September 9, 2016, from http://www.gvglass.info/papers/primary.pdf . 
*Günay, R. (2013). The effect of different organization of activity based learning content on seventh grade mathematics achievement (Unpublished master thesis). Kocaeli University, Kocaeli, Turkey.

*Güngör, S. (2005). Examining the effects of preparing portfolio and hands on materials which is based on the constructivist approach, on students in instructing triangles subject in geometry lesson (Unpublished master thesis). Zonguldak Karaelmas University, Turkey.

Gürbüz, R. (2010). The effect of activity-based instruction on conceptual development of seventh grade students in probability. International Journal of Mathematical Education in Science and Technology, 41(6), 743-767.

Hartzler, D. S. (2000). A meta- analysis of studies conducted on integrated curriculum program sand their effects on student achievement (Unpublished doctoral thesis). Indiana University.

*Helvac1, T.B. (2010). Computer-aided instruction, elementary 6th grade students' mathematics achievement and attitudes in polygons effects topics (Unpublished master thesis). Marmara University, Istanbul, Turkey.

Hunter, J.E., \& Schmidt, F. L. (1990). Methods of meta-analysis: Correcting error and bias in research findings. Sage Publications: London.

İnel, Y., \& Sezer, A. (2017). The effect of the usage of instructional materials on student achievement in teaching geography: a meta-analytic study. Journal of History Culture and Art Research, 6(3), 473-491.

*Kablan, Z. (2010). The effect of using exercise-based computer games during the process of learning on academic achievement among education majors. Educational Sciences: Theory \& Practice, 10(1), 335-364,

Kablan, Z.,Topan, B. \& Erkan, B. (2013). The effectiveness level of material use in classroom instruction: a meta-analysis study. Educational Sciences: Theory \& Practice, 13(3), 1629-1644.

Karakırık, E., \& Aydın, E. (2016). Matematik nesneleri ve sanal manupulatifler. [Learning objects and virtual manipulatives] Doğan, $M$ ve Karakırık, E. (Ed.). Matematik Eğitiminde Teknoloji Kullanımı (2.Baskı) (p.27-46). Ankara. Nobel-Atlas Yayıncılık.

*Kocaman, B.N. (2015). Effect of instruction with manipulatives to mathematics success of $11^{\text {th }}$ grade students (Unpublished master thesis). Y1ldız Technical University, Istanbul, Turkey.

*Koğ, U. O. (2012). The effect of teaching mathematics with visualization approach on students' cognitive and affective development (Unpublished doctoral thesis). Dokuz Eylül University, İzmir, Turkey.

*Konak, Ö. (2009). The effect of group evaluation with bingo cards and worksheets in primary school grade 6th mathematics lesson based on cooperative algebra teaching to students' academic achievement and learning permanency (Unpublished master thesis). Y1ldız Technical University, Istanbul, Turkey.

*Körükcü, E. (2008). The effect of learning integers using visual materials on 6th grade students' success in mathematics (Unpublished master thesis). Marmara University, Istanbul, Turkey.

*Kurak, Y. (2009). The effects of using dynamic geometry software on students' understanding levels of transformation geometry and their academic successes (Unpublished master thesis, Karadeniz Technical University). Trabzon, Turkey.

*Kutluca, T. (2009). Evaluation of a computer assisted learning environment designed for the subject of quadratic functions (Unpublished master thesis). Karadeniz Technical University, Trabzon, Turkey. 
*Küpcü, R. A. (2008). The effect of activity based teaching approach over the proportional reasoning related problem solving achievement (Unpublished doctoral thesis). Marmara University, Istanbul, Turkey.

Lipsey, M. W., \& Wilson, D. B. (2001). Practical meta-analysis. Thousand Oaks, CA: Sage.

Manches, A., O'Malley, C., \& Benford, S. (2010). The role of physical representations in solving number problems: A comparison of young children's use of physical and virtual materials. Computers \& Education, 54, 622-640.

McMillan, J.H. \& Schumacher, S. (2006). Research in education. Evidence based inquiry. 6 edition. Boston: Pearson.

McNeil, N. M., \& Jarvin, L. (2007). When theories don't add up: Disentangling the manipulatives debate. Theory into Practice, 46(4), 309-316.

Ministry of National Education (MONE). (2010). Ortaöğretim (9-12. Sinıflar) Matematik Dersi Öğretim Programı [9-12. Grades Mathematics Curriculum]. Ankara.

Ministry of National Education (MONE). (2017). 1-8 Matematik Dersi Öğretim Programı [1-8. Grades Mathematics Curriculum]. Ankara: MEB.

Moyer, P.S. (2001). Are we having fun yet? How teachers use manipulatives to teach mathematics. Educational Studies in Mathematics, 47, 175-197.

Moyer-Packenham, P. S., \& Suh, J. M. (2012). Learning mathematics with technology: The influence of virtual manipulatives on different achievement groups. Journal of Computers in Mathematics \& Science Teaching, 112(3), 133-146.

Moyer-Packenham, P. S., \& Westenskow, A. (2013). Effects of virtual manipulatives on student achievement and mathematics learning. International Journal of Virtual and Personal Learning Environments, 4(3), 35-50.

National Council of Teachers of Mathematics (NCTM) (2000). Principles and standards for school mathematics. Reston, VA: NCTM Publications.

*Oğuz, A. (2008). The effects of student success of materials prepared according to cd-supported on equations learning subsection (Unpublished master thesis). Marmara University, Istanbul, Turkey.

Ojose, B., \& Sexton, L. (2009). The effect of manipulative materials on mathematics achievement of first grade students. The Mathematics Educator, 12(1): 3-14.

Oldknow, A., Taylor, R., \& Tetlow, L.(2010). Teaching Mathematics Using ICT (3rd.ed). New York: Continuum International Publishing Group.

Olkun, S. (2003). Comparing computer versus concrete manipulatives in learning 2D geometry. Journal of Computers in Mathematics and Science Teaching, 22(1), 43-56.

*Övez, G.M. (2007). The effect of project based learning approach on the student success in mathematics teaching 9th class (Unpublished master thesis). Balıkesir University, Turkey.

*Özerbaş, M. A. (2012). Impact of web quest learning environment on academic achievement and attitudes of students. Kirşehir Journal of Education Faculty, 13(2), 95-104

*Öztürk, B. (2012). Effect of mathematics software GeoGebra mathematics lesson on achievement and van hiele levels of geometric of 8th grades in teaching of trigonometry and slope issues. Unpublished master thesis, Sakarya University, Sakarya, Turkey.

*Öztürk, M. (2011). The effect of computer assisted instruction method on academic achievement on instruction of topics of ratio - proportion (Unpublished master thesis). Erzurum, Turkey. 
Reimer, K., \& Moyer, P. S. (2005). Third-graders learn about fractions using virtual manipulatives: A classroom study. Journal of Computers in Mathematics and Science Teaching, 24(1), 5-25.

Rosenthal, R. (1979). The file drawer problem and tolerance for null results. Psychological Bulletin, 86, 638-641.

Rosenthal, R. (1984). Meta-analytic procedures for social research. Newbury Park, CA: Sage.

*Şahin, M. C. (2005). The effectiveness of internet based distance education: a meta-analysis (Unpublished Master Thesis). Çukurova University, Adana, Turkey

Scherr, T.G. (2004). The educational status of children in foster care. A meta- analytic investigation (Unpublished doctoral thesis). University of Northern Colorado, USA.

Sherman, J., \& Bisanz, J. (2009). Equivalence in symbolic and nonsymbolic contexts: Benefits of solving problems with manipulatives. Journal of Educational Psychology, 101(1), 88 -100.

Sowell, E. J. (1989). Effects of manipulative materials in mathematics instruction. Journal for Research in Mathematics Education, 20(5), 498-505.

Suh, J. M., Moyer, P. S., \& Heo, H.-J. (2005). Examining technology uses in the classroom: Developing fraction sense using virtual manipulative concept tutorials. The Journal of Interactive Online Learning, 3(4), 1-22.

Suydam, M. N., \& Higgins, J. L. (1977). Activity-Based learning in elementary school mathematics: Recommendations from research. ERIC Center for Science, Mathematics, and Environmental Education, Columbus, Ohio.

Sterne, J. A., Sutton, A.J., Ioannidis, J. P., Terrin, N., Jones, D. R., Moher, D., \& Higgins, J. P. (2011). Recommendations for examining and interpreting funnel plot asymmetry in meta-analyses of randomized controlled trials. BMJ (Clinical research ed), 343. d4002. doi: 10.1136/bmj.d4002.

Swan, P., \& Marshall, L. (2010). Revisiting mathematics manipulative materials. Australian Primary Mathematics Classroom, 15(2), 11-17.

Şahin, M. C. (2005). The effectiveness of internet based distance education: a meta-analysis (Unpublished master thesis). Çukurova Üniversity, Adana, Turkey.

*Şahin, T. (2013). Concrete and virtual manipulative-assisted teaching of geometry's impact on the success of building and drawing geometric structures of 5th grade students (Unpublished master thesis). Abant İzzet Baysal University, Bolu, Turkey.

*Şen, N. (2010). The effect of computer-based probability unit designed for the controlling of intuitive thinking on academic success, intuitive thinking and retention (Unpublished master thesis). Cukurova University, Adana, Turkey.

*Şengül, S., \& Körükcü, E. (2012). Effect of Teaching Integers Using Visual Materials on the Sixth Grade Students' Mathematics Achievement and Retention Levels. International Online Journal of Educational Sciences, 4(2), 489-508.

*Şimşek, M. (2012). The effects of origami activities in teaching solid objects on students' achievements (Unpublished master thesis). Ondokuz Mayıs University, Samsun, Turkey.

*Talş1k, E. (2013). The effect of usage of songs composed by the researcher as teaching material in Turkish, math, and social studies lessons on students' success and attitudes development (Unpublished doctoral thesis). Gazi University, Ankara, Turkey. 
Thompson, P. W. (1992). Notations, conventions, and constraints: Contributions to effective uses of concrete materials in elementary mathematics. Journal for Research in Mathematics Education, 23, 123- 147.

*Tuncer, D. (2008). The effect of teaching material aided instruction on 8th. Grade students' academic success and level of permanency (Unpublished master thesis). Gazi University, Turkey.

*Tutak, T., Aydoğdu, M., \& Erşen, A. N. (2014). The Effect Of Mathematics Teaching Supported With Material On 6th Student Success and Attitude. Turkish Journal of Educational Studies, 1(3), 166-185.

*Ubuz, B., Üstün, I., \& Erbaş, A. K. (2009). Effect of Dynamic Geometry Environment on Immediate and Retention Level Achievements of Seventh Grade Students. Eurasian Journal of Educational Research (EJER), (35).147-164.

Ural, G., \& Bümen, N.T. (2016). A meta-analysis on instructional applications of constructivism in science and technology teaching: A sample of Turkey. Education and Science, 41(185), 51-82.

*Üner, İ. (2009). The effects of learning via cartoons on students' success and attitude levels in primary schools (Unpublished master thesis). Marmara University, Istanbul, Turkey.

Ünlü, M. (2017). Pre-service mathematics teachers' views about using instructional materials in mathematics lessons. Journal of Theory and Practice in Education, 13 (1), 10-34.

Üstün, U., \& Eryllmaz, A. (2014). A research methodology to conduct effective research syntheses: Meta-analysis. Education and Science, 39(174). 1-32.

*Yeniçeri, Ü. (2013). The effects of using virtual manipulatives on student's achievement when teaching fractions in primary 6.th class (Unpublished master thesis). Gazi University, Ankara, Turkey.

*Y1lmaz, M. (2005). The effects of using educational technologies in teaching symmetry to success and attitude in 7th class of primary school (Unpublished master thesis). Marmara University, Istanbul, Turkey.

*Y1lmaz, G. K., Ertem, E., \& Güven, B. (2010). Dynamic geometry software of Cabri's influence on 11 grade students' to learn in trigonometry issues. Turkish Journal of Computer and Mathematics Education, 1(2). 200-216.

*Yiğit, Ö. (2008). Effectiveness of fractions instruction software on 4. Grade students' achievement (Unpublished master thesis). Ege University, İzmir, Turkey.

*Yorganci, S., \& Terzioğlu, Ö. (2013). The effect of using interactive whiteboard in mathematics instruction on achievement and attitudes toward mathematics. Kastamonu Education Journal, 21(3), 919-930.

*Yorganci, S. (2014). The effects of web based distance education method on students' mathematics achievements. Kastamonu Education Journal, 23(3), 1401-1420.

Yuan, Y., Lee, C.-Y., \& Wang, C.-H. (2010). A comparison study of polyominoes explorations in a physical and virtual manipulative environment. Journal of Computer Assisted Learning, 26(4), 307-316.

*Zengin, Y. (2011). The effect of dynamic mathematics software GeoGebra on students' achievement and attitude (Unpublished master thesis). Sütcü Imam University, Kahramanmaraş, Turkey. 